forenlig med tidlige tegn på kalsifylaksi og var hos denne pasienten reversible. Det høye kalsiumfosfatproduktet kan ha utløst en akutt myopati som raskt gikk tilbake etter dialyse og bedring av nyrefunksjon og kalsiumfosfatprodukt. Pasienten hadde fra før av kroniske smerter forårsaket av diabetesnevropati, men smertene ble akutt forverret på grunn av en kombinasjon av diabetesnevropati, uremisk polynevropati og inflammatorisk myopati. Pasienten hadde uttalt arteriosklerose og et høyt kalsiumfosfatprodukt, noe vi antar har gitt lokal inflammasjon, hevelse og smerter.

De akutte smertene gikk tilbake i løpet av en uke, parallelt med normalisering av kalsium- og fosfatverdiene. Dette taler for at smertene var forårsaket av kalsifylaksi. Kalsifylaksi er sannsynligvis en underkjent diagnose og er vanligvis assosiert med sårdanning og dårlig prognose (1). Imidlertid har smertefull myopati uten sårdanninger også vært rapportert tidligere (2). Det petekkiale utslettet på leggene forsvant gradvis og ble sannsynligvis utløst av ødemer og økt vevstrykk. Forløpet avkreftet mistanke om infeksjon eller vaskulitt.

Kalsiumfosfatproduktet defineres som produktet av serumverdiene av total kalsium $\mathrm{x}$ fosfat. Ved verdier over $5-6 \mathrm{mmol}^{2} / \mathrm{l}^{2} ø \mathrm{ker}$ risikoen for nedslag av kalsiumkrystaller i nyrer og annet vev, og anbefalt nivå ved alvorlig nyresvikt er $<4$. Høye verdier kan forårsake hudkløe, forkalkninger og i verste fall nekroser, som er typiske for avansert kalsifylaksi, og særlig utsatt er kvinner med overvekt, diabetes og alvorlig nyresvikt (1).

Forverringen i nyrefunksjon antas å være utløst av høyt proteininntak i forbindelse med streng lavkarbodiett. Det er kjent at økt proteininntak kan gi inntil $25 \%$ økning i glomerulær filtrasjonsrate (GFR) fra ut- gangspunktet. Hyperfiltrasjon og økning i glomerulusfiltrasjonen er proporsjonal med mengde protein som inntas (3). Personer med nyresvikt har redusert antall nefroner og dermed dårligere renal reservekapasitet (4). Høyt proteininntak vil da kunne forverre glomerulær skade og nyresvikt (5).

I en studie ble proteininntak og nyrefunksjon hos 1624 kvinner med normal eller lett redusert nyrefunksjon fulgt over en 11-årsperiode (6). Det viste seg at høyt proteininntak hos kvinner med lett redusert nyrefunksjon førte til akselerasjon av nyresvikten. Det er derimot ikke vist at høyt proteininntak påvirker nyrefunksjonen hos friske personer i negativ retning $(6,7)$. Høyt proteininntak er essensielt i de mange lavkarbodiettene som er på markedet og som hyppig omtales i dagspressen uten at helserisiko nevnes.

\section{Konklusjon}

Leger og annet helsepersonell bør kjenne til de potensielt alvorlige bivirkningene et høyt proteininntak kan ha for pasienter med nyresykdom. På grunn av felles risikofaktorer som diabetes og hypertensjon er det en økt forekomst av nyresvikt hos overvektige. Kronisk nyresykdom er ofte asymptomatisk i tidlig fase, men kan påvises ved hjelp av enkle undersøkelser som konsentrasjonsmåling av serum-kreatinin og urin-protein eller urin-albumin. Alle overvektige som ønsker å forsøke lavkarbodiett, bør undersøkes spesielt med tanke på nyresykdom, og pasienter med redusert nyrefunksjon bør advares mot at høyt proteininntak vil kunne forverre nyresvikt.

Pasienten har gitt samtykke til at artikkelen blir publisert.

\section{Heidrun Dahl Olstad (f. 1982}

er lege i spesialisering ved Medisinsk avdeling Forfatter har fylt ut ICMJE-skjemaet og oppgir ingen interessekonflikter.

\section{Einar Svarstad (f. 1948)}

er spesialist i indremedisin og i nyresykdommer. Han er seksjonsoverlege ved Nyreseksjonen ved Medisinsk avdeling. Haukeland univer sitetssykehus og professor ved Institutt for indremedisin ved Universitetet i Bergen. Han har tidligere vært leder av Norsk nyremedi-

sinsk forening.

Forfatter har fylt ut ICMJE-skjemaet og oppgir ingen interessekonflikter.

\section{Litteratur \\ 1. Svendsen EB, Christiansen R, Svarstad E et al. En kvinne med kronisk nyresvikt, progredierende hudforkalkninger og sepsis. Tidsskr Nor Læge- foren 2008; 128: 1295-6. \\ 2. Edelstein CL, Wickham MK, Kirby PA. Systemic calciphylaxis presenting as a painful, proximal myopathy. Postgrad Med J 1992; 68: 209-11. \\ 3. Giordano M, Castellino P, McConnell EL et al. Effect of amino acid infusion on renal hemodyna- mics in humans: a dose-response study. Am J Physiol 1994; 267: F703-8. \\ 4. Bosch JP, Saccaggi A, Lauer A et al. Renal functional reserve in humans. Effect of protein intake on glo- merular filtration rate. Am J Med 1983. 75. 943-50. \\ 5. Friedman AN. High-protein diets: potential effects on the kidney in renal health and disease. Am J Kidney Dis 2004; 44: 950-62. \\ 6. Knight EL, Stampfer MJ, Hankinson SE et al. The impact of protein intake on renal function decline in women with normal renal function or mild renal insufficiency. Ann Intern Med 2003; 138: 460-7. \\ 7. Brinkworth GD, Buckley JD, Noakes M et al. Rena function following long-term weight loss in individ- uals with abdominal obesity on a very-low-carbo- hydrate diet vs high-carbohydrate diet. J Am Diet Assoc 2010; 110: 633-8.}

Mottatt 12.9. 2011, første revisjon innsendt 4.12. 2011, godkjent 8.12. 2011. Medisinsk redaktør Trine B. Haugen.

\title{
Nyresvikt, fedme og kosthold
}

Denne sykehistorien støtter teorien om at en streng lavkarbodiett kan forverre nyreskade hos diabetikere med kronisk nyresvikt.

Hver tiende nordmann har kronisk nyresykdom (1), og forekomsten er spesielt høy hos overvektige personer med fedmerelaterte følgesykdommer som hypertensjon og type 2-diabetes. Vårt vestlige kosthold, med et høyt inntak av energitette matvarer som inneholder mye sukker, mettet fett og salt, kan være en viktig risikofaktor for kronisk nyresykdom (2).

Lavkarbohydratdietter har vært varierende populære i mer enn 150 år (3). Den strengeste formen tillater inntil $20 \mathrm{~g}$ karbohydrater daglig, oftest mindre enn $5 \%$ av totalt energi- inntak. Dermed økes det relative protein- og fettinntaket (f.eks. henholdsvis $35 \%$ og $60 \%$ ). Flere epidemiologiske studier har vist at et høyt proteininntak kan være skadelig for personer med lett nyreskade, mens andre ikke har kunnet bekrefte dette (2).

Kostholdets sammensetning er spesielt viktig for personer med kronisk nyresykdom, både for å minimalisere risikoen for hjerteog karsykdom, og for å redusere opphopning av avfallsstoffer og forverring av nyresykdommen (1). Internasjonalt anbefales et proteininntak som ikke er høyere enn $0,8 \mathrm{~g} / \mathrm{kg}$ hos diabetikere som har kronisk nyresykdom (4). Den aktuelle pasienten kan ha hatt et 2-3 ganger høyere proteininntak enn anbefalt, og det er sannsynlig at dette kan ha bidratt til forverring av nyrefunksjonen.

Lavkarbodietten kan imidlertid også initialt ha utløst en prerenal nyresvikt forårsaket av kombinasjonen av dehydrering, arteriosklerose og behandling med ACEhemmer. Streng karbohydratrestriksjon kan gjennom flere mekanismer øke diuresen, blant annet ved tømming av glykogenlagrene i lever og muskulatur (3). Minst halvparten av de $4 \mathrm{~kg}$ som pasienten tapte den første uken, kan forklares av væsketap.

Pasienten ble også behandlet med gabapentin i høyere dose enn anbefalt i forhold til grad av nyresvikt, og det kan ikke utelukkes 
at gabapentinindusert myopati og rabdomyolyse (mangler CK-verdi) kan ha bidratt til forverringen (5).

Selv om den vitenskapelige dokumentasjonen ikke er overbevisende, taler trygghetshensyn for at strenge lavkarbodietter bør unngås hos personer med redusert nyrefunksjon. De nye norske kostrådene kan derimot trygt brukes av personer med kronisk nyresykdom som har beskjedne symptomer $(1,4,6)$.

\section{Jøran Hjelmesæth}

joran.hjelmeseth@siv.no

Senter for sykelig overvekt i Helse Sør-Øst

Sykehuset i Vestfold

Jøran Hjelmesæth (f. 1957) er dr.med., indremedisiner og nefrolog. Han leder Senter for sykelig overvekt i Helse Sør-Øst ved Sykehuset i Vestfold og er formann i Norsk forening for fedmeforskning.

Forfatter har fylt ut ICMJE-skjemaet og oppgir ingen interessekonflikter.

\section{Litteratur}

. Handlingsplan for forebygging og behandling av kronisk nyresykdom (2011-2015). Oslo: Helsedirektoratet, 2011. www.nephro.no/foreningsnytt/ Handlingsplan_forebygging_behandling_kronisk_ nyresykdom.pdf

2. Odermatt A. The Western-style diet: a major risk factor for impaired kidney function and chronic kidney disease. Am J Physiol Renal Physiol 2011; 301: F919-31.

3. Astrup A, Meinert Larsen T, Harper A. Atkins and other low-carbohydrate diets: hoax or an effective tool for weight loss? Lancet 2004; 364: 897-9.

4. Bakris G, Vassalotti J, Ritz E et al; CKD Consensus Working Group. National Kidney Foundation consensus conference on cardiovascular and kidney diseases and diabetes risk: an integrated therapeutic approach to reduce events. Kidney Int 2010 78: $726-36$

5. Tuccori M, Lombardo G, Lapi F et al. Gabapentininduced severe myopathy. Ann Pharmacother 2007; 41: 1301-5.

6. Nasjonalt Råd for ernæring. Kostråd for å fremme folkehelsen og forebygge kroniske sykdommer.

Metodologi og vitenskapelig kunnskapsgrunnlag. IS-1881. Oslo: Helsedirektoratet, 2011.

Mottatt 6.1. 2012, første revisjon innsendt 16.1. 2012, godkjent 16.1. 2012. Medisinsk redaktør Are Brean. 